\title{
REGIONAL SUPPORT FOR INTERNATIONALIZATION OF SMES - CASE STUDY OF THE AUTONOMOUS REGION OF VALENCIA
}

\author{
Tomasz SZULC \\ Silesian University of Technology, Department of Management and Logistics; tomasz.szulc@polsl.pl, \\ ORCID: 0000-00034823-7667
}

\begin{abstract}
Purpose: The objective of the paper is to identify the activities, interorganizational relations among implementing institutions and formulas of their financing, in order to facilitate access to international markets by small and medium-sized enterprises.
\end{abstract}

Design/methodology/approach: Methodology of the paper comprises critical literature review on internationalization, interviews with the representatives of institutions rendering services form SMEs (regional administration and the Chamber of Commerce) as a part of a case study, as well as observation. Theoretical framework of the paper was prepared with a use of critical literature review. Analysis of the business environment of Valencia Autonomous Region was prepared with the application of observation conducted by the author and analysis of secondary sources, mainly regional statistics. The main part of the research was conducted with the use of direct interviews with the employees of the regional and municipal administration and business support organizations.

Findings: The literature provides a variety of definitions and paradigms of internationalization. Only a minor part is exercised in practice by the businesses. The majority follows the internationalization path determined in the Uppsala model, however SMEs do not rather proceed to foreign direct investments. Based on the interviews it was determined, that the regional authorities of Valencia provide a range of support services, concentrating financial resources on practically three of them which demonstrate the highest effectiveness and lead to best results in terms of increase of share of exports in the regional GDP.

Research limitations/implications: Due to confidentiality, financial indicators concerning public spending, financial participation, as well as the names and respective shares of export net sales revenues were not revealed by the representatives of the Chamber of Commerce.

Practical implications: Identified services may be used as a best practice for similar organisations (regional government, business support units) for designing their local mutations of export supporting services.

Originality/value: The paper is a comprehensive analysis of public services supporting regional exports and their conformance with the theoretical models of internationalization.

Keywords: internationalization, support services, business development, Uppsala model.

Category of the paper: research paper, case study. 


\section{Introduction}

Development of businesses in modern times requires concentration on larger scale operations and activities, regardless of the size of the enterprise. Whether it is a micro- or SME, or a Large Enterprise, it needs to consider its activity, but also competitors on a global market. Even the smallest enterprises, having unique and quality products and a deep understanding of their customers' needs and their nuances varying across the globe, can internationalize successfully and become a recognized global player. Of course, each company as limited resources to undertake such activities, therefore proper decisions and support from the public authorities is absolutely vital for it to succeed. The article presents activities provided with the financial and institutional support of the public authorities of the Autonomous Region of Valencia in Spain. It focuses on particular activities animated by IVACE, the regional Institute of Business Competitiveness. Valencian Institute of Business Competitiveness is a public entity of the Valencian government attached to the Regional Department of Economy, Industry, Tourism and Employment. There was identified a research gap between the content of so far published material and the topic of this paper. Most of current and past research concentrated on describing the paths of international expansion exercised primarily by large enterprises. They are mainly powerful businesses having sufficient financial potential, which may make use of business diplomacy of their home countries to design their expansion, whereas SMEs, particularly the start-ups, are missing such a support or have not enough power to benefit from national foreign business policy. As micro- and SMEs have a significant share in creation of GDP (ca. 50\%), it is necessary to identify services which they may use and, consequently, their paths of expansion. However, identification of paths of expansion will be possible after the first groups of beneficiaries of the services enter foreign markets successfully over next few years. The article is a part of broader research on regional activities supporting international expansion of SMEs.

\section{Theoretical framework for the processes of internationalization}

Small and Medium-Sized Enterprises play a vital role in the economy. According to the OECD statistics, they represent more than $95 \%$ of all companies; they are also responsible for creation of approximately $70 \%$ of jobs. The figures are comparable both in developed economies, as well as in the emerging ones. It indicates that they play a strategic role in the economy. Previous research (Miesenböck, 1988, Lu and Beamish, 2001, Rialp and Rialp, 2001, Doole et al., 2006) concentrated mainly on mature, large corporations, which had sufficient resources and potential to go international with their activities. However, the due to the 
significance of SMEs, the literature proposes more and more analyses of their behaviour on the international markets. There are different definitions of internationalization, presenting various types of focuses. They are provided in table 1.

Table 1.

Selection of definitions of internationalization

\begin{tabular}{|c|c|c|}
\hline Author & Definition & Concentration \\
\hline $\begin{array}{l}\text { Welch and } \\
\text { Luostarinen (1993) }\end{array}$ & $\begin{array}{l}\text { Internationalization is the outward movement of a } \\
\text { firm's international operations }\end{array}$ & Process, firm's operations \\
\hline $\begin{array}{l}\text { Calof and Beamish } \\
(1995)\end{array}$ & $\begin{array}{l}\text { Internationalization is the process of increasing } \\
\text { involvement in international operations }\end{array}$ & Process, firm's operations \\
\hline $\begin{array}{l}\text { Johanson and } \\
\text { Mattson (1993) }\end{array}$ & $\begin{array}{l}\text { Internationalization is the process of adapting firms' } \\
\text { operations (strategy, structure, resources etc.) to } \\
\text { international environments }\end{array}$ & Process, firm's operations \\
\hline $\begin{array}{l}\text { Johanson and Vahlne } \\
\text { (1990) }\end{array}$ & $\begin{array}{l}\text { Internationalization as a cumulative process in which } \\
\text { relationships are continually established, developed, } \\
\text { maintained and dissolved in order to achieve the firm's } \\
\text { objectives }\end{array}$ & Relationships, process \\
\hline $\begin{array}{l}\text { Lehtinen and } \\
\text { Penttinen (1999) }\end{array}$ & $\begin{array}{l}\text { Internationalization as developing networks of business } \\
\text { relationships in other countries through extension, } \\
\text { penetration and integration }\end{array}$ & Networks, relationships \\
\hline $\begin{array}{l}\text { Lehtinen and } \\
\text { Penttinen (1999) }\end{array}$ & $\begin{array}{l}\text { Internationalization concerns the relationships between } \\
\text { the firm and its international environment, derives its } \\
\text { origin from the development and utilization process of } \\
\text { the personnel's cognitive and attitudinal readiness and } \\
\text { is concretely manifested in the development and } \\
\text { utilization process of different international activities, } \\
\text { primarily inward, outward and cooperative operations }\end{array}$ & $\begin{array}{l}\text { Relationships, firm's } \\
\text { operations, } \\
\text { process, int. environment }\end{array}$ \\
\hline Ahokangas (1998) & $\begin{array}{l}\text { Internationalization is the process of mobilizing, } \\
\text { accumulating and developing resource stocks for } \\
\text { international activities }\end{array}$ & Resources, process \\
\hline
\end{tabular}

Note. Adapted from: (Ruzzier, Hisrich, Antoncic, 2006, p. 479).

A comprehensive overview of approaches towards internationalization were presented by Wolniak (Wolniak, 2019) where he indicates on variety of definitions but emphasizes fine differences between globalization and internationalization. It is underlined that historically globalization is related more to the economy, market and technology rather than the business itself. Further research proposed by Wolniak is focused on indicators of internationalization (Wolniak, 2020), where he identifies a set of measures concentrated on efficiency of going global not only for individual enterprises, but for networks or clusters of businesses.

It is also clearly indicated in the articles that a sole SME is less likely to succeed when going global than a cluster or a network of such companies (Hutchinson et al., 2005, Pantin, 2006, Laghzaoui, 2011, Wolniak, 2020). There is a sound theoretical background of internationalization developed in the literature, indicating three different approaches to this problem: (1) economic approach, (2) stages approach and (3) network approach. 
The first approach was summarized by Ruzzier et al. (Ruzzier et al., 2006), where they identified:

- Theory of internalization,

- Transaction cost theory,

- The eclectic paradigm.

The theory of internalization assumes that the company pursues development of its own internal market and the transactions can be made at a lower cost within the firm and will continue until the balance of future costs and benefits of internalization is positive, comparing to the margin (Buckey and Casson, 1995). Internalization can be done in the form of vertical integration bringing new operations and activities, previously delivered by intermediate companies under the ownership and governance of the firm, especially when natural markets are imperfect or missing. Internalization of transactions abroad leads to the creation of the multinational enterprise (MNE). Early stage of internalization is a process of information gathering and assessment, through which management determines the best foreign expansion approach.

Transaction cost theory indicates that internationalization, in particular its forms, is seen as the result of a choice made by the firm between the internalization and the externalization (outsourcing) of its activities. Profit-seeking firms internalize and outsource various operations, when by so doing the costs of organizing and transacting business may be lowered. This theory constitutes a prolongation of the theory of the internalization and was developed by Williamson (Williamson, 1975; Gilroy, 1993; Laffranchini, 2016).

The eclectic paradigm, known also as OLI is founded on the theory of internalization. It emphasizes the role of launching operations of the company in foreign countries, but also determines the selection of foreign markets for company's direct investment (so called Foreign Direct Investment). In the eclectic paradigm, internationalization is determined by three types of advantages that the company needs to gain. Dunning distinguishes:

- ownership advantages which are specific to the firm and related to the accumulation of intangible assets, technological capacities or product innovations,

- internalization advantages stemming from the capacity of the firm to manage and coordinate activities internally in the value-added chain,

- location advantages referring to the institutional and productive factors present in given geographical area (Dunning, 1998).

As indicated by Laghzaoui, the aforementioned theories, since developed for large firms, may be difficult in extrapolating to particular needs of SMEs. Additionally, they tend to oversee social relations in transactions (Gemser et al., 2004). 
Ruzzier et al. indicate also theory of monopolistic advantage which says that MNEs exist because a firm has unique sources of superiority over foreign firms in their own markets. The advantages belong to the MNE and cannot be acquired elsewhere, and the superiority may be identified in the fields of knowledge, products, processes, brand names or patents.

The stages approach to internationalization is based on two models - Uppsala model (U-model) and Innovation-related internationalization model (I-model). Both of them assume, that going to the foreign market is a sequential and linear process composed of steps that need to be made in order to start sales or operations abroad.

In the Uppsala model, internationalization of the company is considered as a process of increasing its an international involvement as a result of different types of learning. According to the model, it is proposed that the general and experiential market knowledge and resource commitment of firms (state aspects) affect commitment decisions and current business activities (change aspects). The change aspects increase the market knowledge and stimulate further resource commitment to foreign markets in the subsequent cycle (Andersen, 1993). Companies increase their international presence in small incremental steps within foreign markets in which they currently operate (Johansson, Vahlne, 1977, 2009, 2011, 2013). The U-model assumes 4 stages of international activity of the company:

- occasional exporting,

- exporting through sales agents in new markets,

- establishment of sales subsidiaries in foreign market,

- starting the production in the foreign market through wholly owned subsidiaries.

The ultimate stage is associated with benefiting from ownership, location and internationalization advantages to a full extent. U-model considers knowledge about specifications of new markets as a critical factor of success in respective market. Johansson and Vahlne revised their model to take into account important changes in the global business environment and the criticism made by other researchers who indicate the determinism and linearity of the U-model (Coviello, McAuley, 1999; Forsgren, 2002). The main argument against the model is that neither does it explain the initiating conditions of the process nor why, how and when internationalization starts. They also argue that the process is not linear and hardly measurable. In the revised model, Johanson and Vahlne consider the growing importance of business networks and strategies for the international expansion of companies.

The I-model considers internationalization as a process the stages of which can be similar to those of new product development or more generally - as an innovation to the company. There are identified three generic stages: the pre-export stage, the initial export stage, and the advanced export stage. This model is adopted exclusively to the exporting activities. The suggested stages of the I-model may be described by the following characteristics: 
- pre-export stage: firms interesting only by the national market, firms seriously planning to export; firms having already exported but do not do it anymore,

- initial stage: firms implying in an irregular way in export while having the potential to extend their activities abroad,

- advanced phase: firms exporting regularly with an experience extended abroad; firms considering of other forms of engagement the international one (Leonidou, Katsikeas, 1996).

An interesting study of stages approach is proposed by Dominiguez and Mayrhofer. They identified new patterns of SME internationalization, taking into account (1) the speed of internationalization, (2) the concept of de-internationalization and (3) the concept of re-internationalization (Dominiguez, Mayrhofer, 2017). In terms of speed of internationalization, it has been observed that accelerations is identified more frequently than a slow-down, despite limited market knowledge, networks and experience. (Kalinic, Forza, 2012). Others describe the concept of de-internationalization which refers to voluntary and forced actions that reduce or stop a firm's engagement in foreign activities. The withdrawal from foreign markets can take various forms:

- reduction of operations in a given market or withdrawal from that market,

- switching to operation modes involving less commitment,

- sell-off or closure of foreign subsidiaries,

- reduction of ownership stake in foreign subsidiaries,

- seizure by local authorities of assets owned by the company (Benito, Welch, 1997).

Welch and Welch develop the concept of re-internationalization where companies withdraw from foreign operations before re-entering international markets. Some companies go into the re-entry process with a significant heritage from previous international activities, including relevant knowledge and networks, which facilitates a faster re-entry (Welch, Welch, 2009).

Another group of companies that internationalize are so called Born Globals (BGs). BGs typically are younger SMEs characterized by limited resources, but despite this constraint, countless such firms now generate substantial trade flows across the global economy. They are widely recognized as important, distinctive organizations in global trade. The evidence points to BGs and internationalizing SMEs as having attained legitimacy in the research. However, more work is needed, particularly regarding the development of explanatory models and theoretical perspectives. (Knight, Liesch, 2016). Bell et al. (2001) refer to the BGs concept and extend this framework to a new form of companies called Born-again globals. These firms are already well established in their domestic markets, with no motivation to internationalize, but who suddenly decide to rapidly develop their activities in foreign markets due to a critical event or opportunity (Bell et al., 2001). Opportunities refer to cross-national combinations of resources and markets (Gregorio, Musteen and Thomas, 2008; Mathews and Zander, 2007). McDougall and Oviatt (2000) emphasized the discovery and pursuit of opportunities outside 
the firm's domestic markets in pursuit of competitive advantage. (Knight, Liesch, 2016). The BG companies stay in contradiction to traditional incremental models of internationalization defined by I- and U-model.

This literature review forms a sound theoretical foundations for further research. It is dubious, whether the SMEs have sufficient resources to be immediate BGs, but it may be subject to further research. It may be also interesting to investigate the approach and attitude of start-ups towards going global on the spot or delaying such decision until gaining a better competitive position on domestic market.

\section{Business characteristics of the Autonomous Region and the City of Valencia}

The objects of this research are: the Comunidad Valenciana - Autonomous Region of Valencia (referred to later as ARV) and the City of Valencia (referred to later as CV). The ARV covers the area od 23255 sq. kms and is inhabited by 4,95 millions of citizens. The capital city of the region is Valencia, which is the 3rd largest municipality in Spain. The region is divided into 3 provinces: Castellon, Valencia and Alicante. The rough administrative division and the location of the region on Iberian Peninsula and in Spain, is provided on the map (Figure 1).
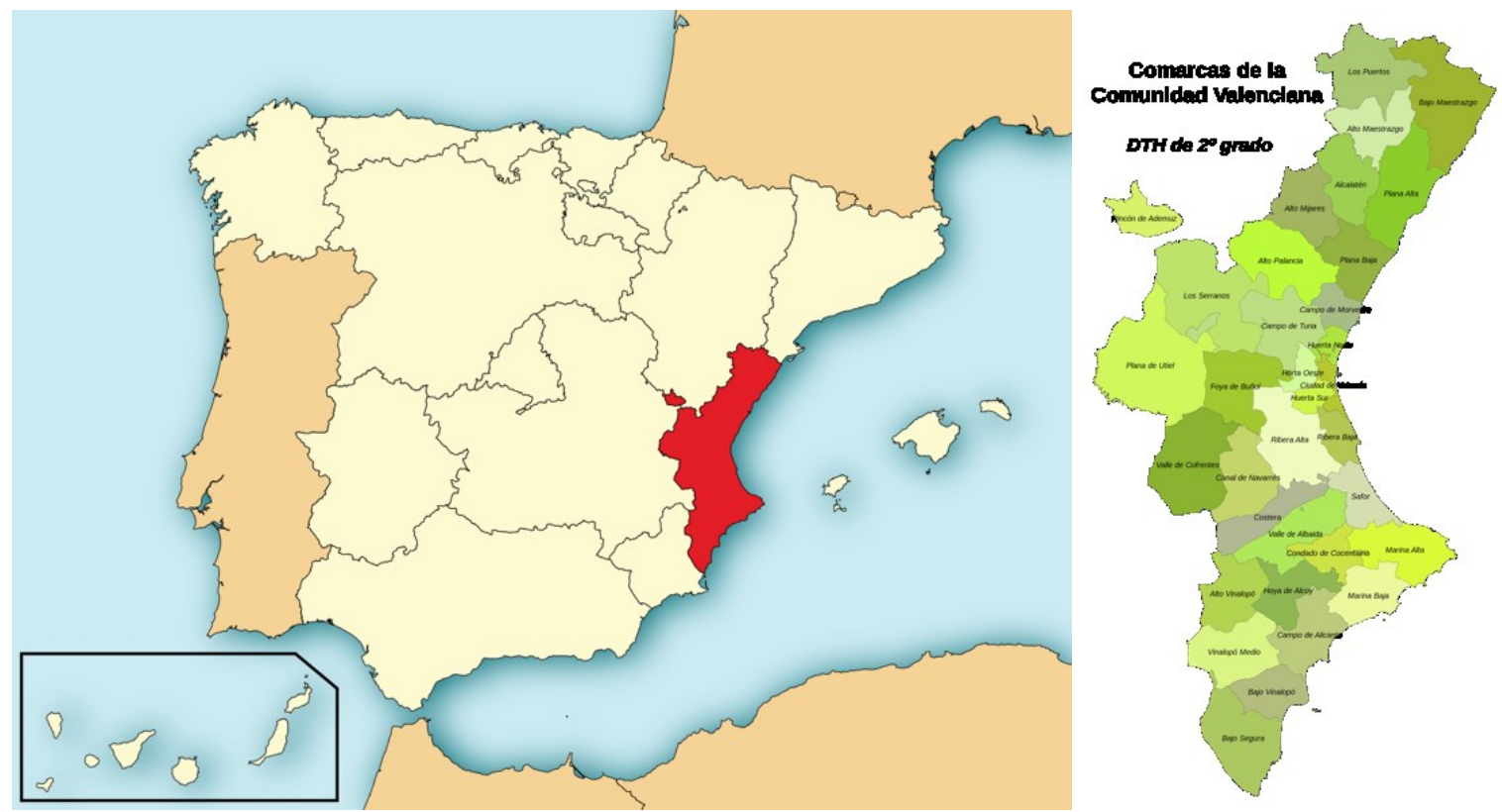

Figure 1. Location of the Valencia Autonomous Region on Iberian Peninsula. Source: Open source maps. 
The region is governed by the parliament and the cabinet. Valentian parliament (Corts Valencianes) is the legislative body consisting of 92 members elected for a four-year term of office. The executive body is the government (Generalitat Valenciana) chaired by the President.

The city is governed by the municipal council and the mayor. The council (Pleno del Ayuntamiento) consists of 33 members, the executive body is the mayor of the city (Alcalde).

The distribution of regional gross domestic product is provided in the graph (Figure 2).

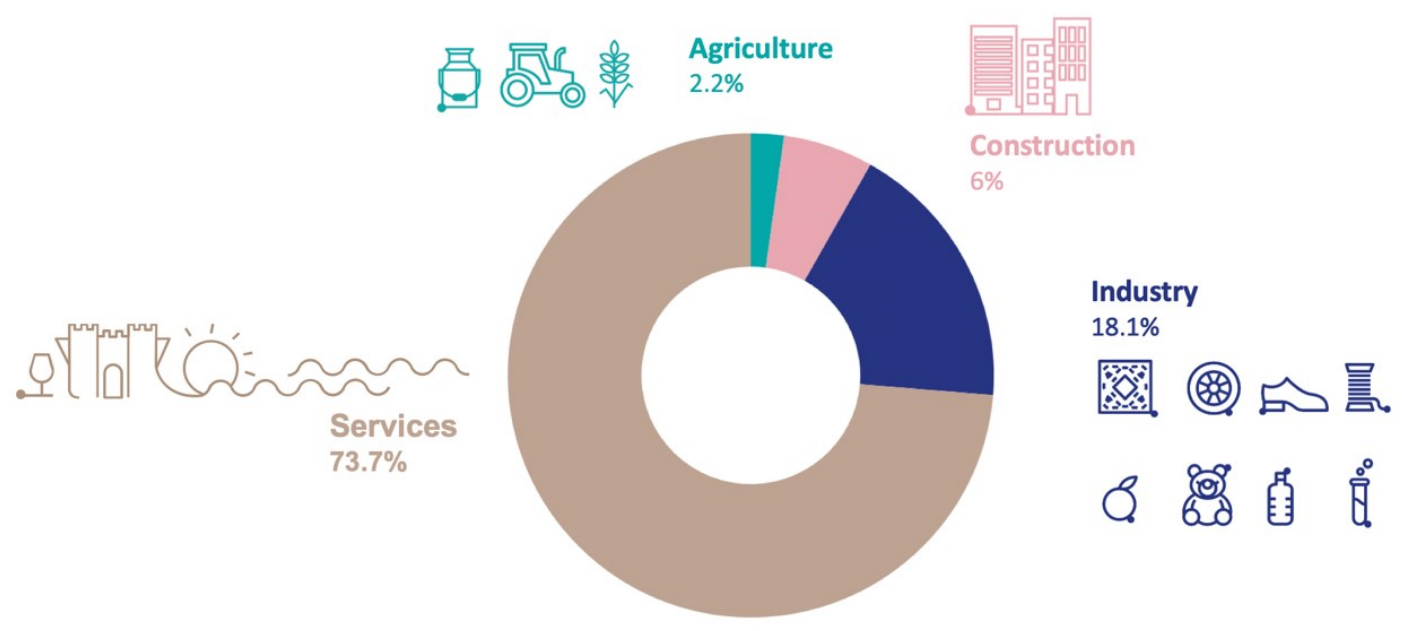

Figure 2. Strtucture of the regional gross domestic product of the Valencia Autonomous Region, source: own elaboration based on National Institute of Statistics data, 2018 (INE).

According to the statistics provided by Spanish INE, Valencian regional economy is founded primarily on services $(73,7 \%)$, the industry creates $18,1 \%$ of the regional GDP and the remaining share is covered by agriculture and construction. The most important industries comprise: machines, automotive, FMCG, fashion, toys and chemicals.

The regional government indicates the following advantages in terms of business cooperation with and in the region:

- favourable location in the centre of the Mediterranean region,

- high quality transport infrastructure,

- accessibility to all modes of transport (maritime, aviation, terrestrial),

- high level of research and development activity of the regional universities and innovation networks,

- highly qualified professionals on the labour market,

- very good conditions influencing the quality of life,

- strong institutional support from the public administration.

The main organisation responsible for facilitating the regional businesses in their expansion and attracting foreign businesses to invest in the ARV is the Institute of Business Competitiveness - IVACE which is a subsidiary of the regional government. This organisation comprises 4 functional units responsible for: international relations, innovations, development 
of industry and energy. The international unit is responsible for attraction of foreign investments, creation of favourable conditions and delivery of support services for the inbound investors as well as for delivery of services facilitating global growth of Valencian businesses, particularly SMEs. It also provides financial support for such activities as it plays the role of the managing body of some part of European funds allocated for business development. IVACE closely cooperates also with the local governments as some of the services delivered to SMEs have a complimentary nature and the enterprises may customise the mix of them which is the most suitable for their needs.

\section{Regional tools for supporting SMEs in their activities of the international markets}

The first group of services provided by IVACE is focused on facilitation of international expansion of the businesses. The region offers distinctive services for two types of businesses: newcomers and experienced exporters. The first service called XPANDE / XPANDE Digital. As indicated earlier, it is addressed exclusively to new exporting companies which do not have sufficient knowledge and experience in this type of activity. The objective of XPANDE, beside facilitating the businesses to start exporting, is to increase the global recognition of the Valencia Region. Moreover, it is aimed at diversification of the destination markets on which local and regional businesses may operate.

The specific objectives of XPANDE / XPANDE Digital comprise:

- implementation of a methodology of development of feasible and sustainable Export Plan for the business,

- facilitation in selection of a potential foreign market according to the strengths of organisation's products,

- provision of the strategy of penetration of the indicated markets with a draft of a positioning and commercial promotion plan of the products,

- operationalisation of the strategy and its exercising on the foreign market with execution of trial sales.

The service is oriented particularly on human resources of the future exporters as it provides hybrid activities. The first group is focused on increase of knowledge and awareness of the entrepreneurs and their personnel in order to build exporting capacity of the organisation. It is achieved mainly by in-house training and consultancy services delivered by the experts delegated by IVACE in cooperation with the Chamber of Commerce. Individualised consulting sessions are divided in to 4 modules covering the following topics: selection of products, customers and foreign markets, preparation of the strategy of entry, marketing plan and business plan. These 4 topics consume roughly 48 hours of individualized sessions. The service is 
delivered in two phases. First of them is focused on consulting and training. Practically it is free of charge for the business, as $80 \%$ of the total cost is covered by the European Regional Development Fund and $20 \%$ by the Chamber of Commerce. The cost does not exceed 4600 Euro. Should any problems emerge at this stage, the risk of the business is extremely low as it all takes place prior to starting physical sales on the foreign market and incurring any additional cost on it. The second phase of XPANDE / XPANDE Digital is more costly as it totals up at the level of 15000 Euro. Therefore, the entrepreneur - in order to proceed - needs to contribute in these costs in roughly $20 \%$, and $50-70 \%$ is covered from the European funds. The missing part is covered by the Chamber of Commerce. This stage concentrates on starting physical presence on the foreign market, particularly by participation in international fairs (incl. cost of travel and accommodation), organisation of points of sales, translation and delivery of promotional materials, websites, execution of in-depth market research delivered by specialised companies, as well as organisation of trial sales. XPANDE Programme has got its digital mutation indicated as XPANDE Digital. Practically it offers very similar types of services but it is oriented towards digital products or services promoted with the use of digital media. This service is used mainly by born-globals, operating in ICT industry. In particular it is focused on:

- designing and creation of campaigns in Google AdWords (SEM), CPC/CPM campaigns.

- modification, expansion and reform of the websites regarding organic positioning (SEO),

- preparation of web analytics; general integration, setting goals and conversions, creating customised dashboards,

- content generation actions "content marketing",

- e-mail marketing actions,

- digital tools to reinforce customer acquisition, development and customer loyalty strategy,

- designing and creation of campaigns in Social Networks (SMM),

- creation and design of landing pages, microsites,

- registration in directories and / or marketplaces,

- editing, creating videos for social networks.

Another service delivered in the ARV focused on global expansion of mature businesses is called Sicomex. It is implemented together by IVACE and ARVET - Valencia Exporters' Federation. The costs of all operations are covered by the businesses, additionally they are obliged to cover the success fee for the agent, however it is possible to receive co-financing from the regional budget. As indicated earlier, this service is addressed to more mature businesses which have a sound sales potential abroad. The key factor of success in Sicomex is consolidation of offers. The main objective of this service is assistance to the businesses in 
preparation and organisation of permanent sales structures in the destination markets by building partnerships between local and foreign SMEs. Within this service a group of businesses having offering complimentary goods or services form some kind of sales group or association and hire a local expert on given, specific foreign market, who acts as a commercial agent and sales representative for this small group of enterprises. The expert is required to have sound market research competency and thorough knowledge concerning local business conditions. A main part of a job of such a person is to prepare commercial implementation of the products, explore the distribution channels, examine the conditions and prepare cooperation agreements. The expert must look for commercial information and perform market intelligence related to particular industry or industries, from which the Valencian businesses come. The main objectives of this service include: acquisition of knowledge concerning customer preferences, commercial implementation of a portfolio of complimentary products, setting of distribution channels on foreign markets, feasibility assessment of potential joint ventures or strategic alliances, acquisition of licences, certification for products on a foreign market. Finally, the expert also estimated the possibilities of direct investing abroad, however, small and medium sized enterprises demonstrated no readiness for this kind of service. As indicated earlier, Sicomex helps recruiting an expert. Therefore, the maximum number of participants of such kind of "sales consortium" should not exceed 3-8 companies. Such an agent has all powers (sometimes power of attorney) to represent these companies for a period of 2 years. The main difference between this construction and a formal export consortium (known well from Italian practice), lies in its lack of legal personality and rather shorter period of validity.

The service is delivered in two stages, the first of which comprises:

- analysis and configuration of potential distribution channels,

- analysis of legal framework for sales of given class or type of product, determining the requirements for basic and extended certification, permissions, etc. essential for entering the market,

- analysis of competitors, assessment of the size and dynamics of the market, potential for growth and customer preferences.

At this stage the participant (user) of the service may make a decision concerning withdrawal or may decide to proceed. The second stage concentrates of follow-up of potential customers and signing the tri-lateral trade agreements. The first year of activity focuses on market investigation and exploration of legal issues, as well as on identification and sales to the first customers, the second year - as a consequence - is focused on monitoring and deeper penetration of the market, to further increase of sales. Once the position of the companies is established on the foreign market, the agent withdraws and the bi-latera trade agreements enter into force. The service is delivered in 11 regions of the world on all continents, but according to the declarations by the representatives of ARVET, the best results in terms of sales are observed in Latin America. During the interviews the respondents underlined that one of the 
factors of success is cultural proximity and no language barriers. In these terms, Latin America seems to be the most favourable location due to existence of both aforementioned factors.

The financial results of both services - XPANDE and Sicomex were not revealed during the interview due to confidentiality clauses in the contracts signed by the businesses with the Chamber of Commerce and the Federation of Exporters.

The meaning of low cultural distance was also observed for the project called RedEmprendia, implemented by the network of universities on Iberian Peninsula and in the Iberoamerican countries. It is focused on acceleration of commercialisation of technologies developed in the universities in Spain (a.o. University of Valencia and Technical University of Valencia), Portugal, Chile, Argentina, Brazil, Mexico, Colombia and Peru as a result of international research projects. Competitive talents from both sides of the Atlantic Ocean demonstrate ease in building virtual teams and due to lack of language barriers and minor cultural differences, collaborate and conduct joint projects. The project offers exchanges of start-ups, financial support and infrastructure of business incubators and co-working spaces. This project created a huge ecosystem of innovations exceeding the natural borders and barriers. Project administration reports more than 100 start-ups and spin-off to be established as a result of transatlantic cooperation.

The last initiative supporting SME activity on domestic and foreign markets is VIT Emprende, implemented locally by the Municipality of Valencia. VIT Emprende is Valencia's network of innovative entrepreneurs that the Municipality launched via Fundación InnDEA Valencia. The main objective of the activity was to deliver high quality business trainings for future entrepreneurs. Later in this initiative was enriched with joint promotional events, networking events and delivery of physical infrastructure. The initial sum of money for which an entrepreneur may apply must not exceed 60000 Euro. Through these activities, reports say that there were established 500+ start-ups, operating in 16 accelerators, supported by 15 venture capital funds and other financial institutions. From 2012 until 2019 more than 2500 persons participated in project's operations. It means that almost $20 \%$ of the participants decided to start their businesses.

Due to confidentiality, some of the financial information was not revealed during the interviews, however, from the point of view of development of the Valencian economy, these activities are valued as since the beginning they have been strongly supported by both regional and local governments. 


\section{Discussion of the results and conclusions}

Comparing the theory and the practical solutions implemented in Valencia it may be concluded that all of the aforementioned support services provide assistance in internationalisation of businesses up to the 3rd stage of the Uppsala model. It is absolutely understandable, as if the organisation is ready to establish its subsidiaries overseas (i.e. is ready to conduct the foreign direct investment), it requires minor support from the external bodies as it has got sufficient powers to conduct market research and assess its chances abroad on its own.

Delivery of internationalisation services requires strong financial support. Valencia region applies financing-mix from various sources, including private ones. It was confirmed that the contribution of the regional authorities is significant, it applies both European funds allocated to given region, as well as its national resources to stimulate the exports of Valentian businesses. Both XPANDE and Sicomex are supported from EU budget, and VIT Emprende is a programme financed from the municipal budget of Valencia.

One of the factors of success in this area, is creation of the ecosystem of organisations exceeding the continental borders. Such ecosystem was successfully built within RedEmprendia project, covering Spanish-speaking countries from Europe and Latin America. Within the region all activities are concentrated primarily on SMEs, which are addressed the support services.

Foreign direct investments were not executed by the SMEs from Valencia. There was no evidence delivered during the interviews, that any SME decided to start its activity abroad in such form. The main reason of such situation was lack of financial capacity to conduct all activities regarding either acquisition of an existing business abroad or establishing own facilities there. On the other hand, both XPANDE and Sicomex demonstrated high popularity as per each call for applications at least 50 businesses developed their internationalization strategies (total amount ca. 300) and roughly 60 sales networks employed their agents in foreign market and started exporting, primarily to Latin America countries.

Comparing the offer for SMEs from Valencia and from Emilia-Romagna in Italy (Szulc, 2020), it may be also concluded that the services provided there have totally different nature and are rendered in more dispersed business support environment, primarily on the local level. Moreover, Emilia-Romagna bases all its support on the multiannual programme "ER Go Global" where the target market and priorities are set on an administrative level, and Valencia leaves more freedom of choice for the businesses, softly indicating potential foreign markets. A collection of the most popular supporting services from most EU member states may act as a comprehensive guidebook for internationalization of the academia and enterprises. 
In order to construct a comprehensive picture of services supporting internationalization in the EU, further research must be conducted. The author is planning to proceed to the examples of Swedish region of Gävleborg and South Yorkshire in the UK.

\section{Acknowledgements}

The article was prepared within a statutory research project no 13/040/BK/20/0085 Modern methods of management of business, city and region executed in the Department of Management and Logistics of the Faculty of Organisation and Management of the Silesian University of Technology.

\section{References}

1. Andersen, O. (1993). On the internationalization process of firms: A critical analysis. Journal of international business studies, 24(2), 209-231.

2. Bell, J., McNaughton, R., Young, S. (2001). Born-again global'firms: An extension to the 'born global' phenomenon. Journal of international management, 7(3), 173-189.

3. Buckley, P.J., Casson, M. (1995). The Economic Theory of Multinational Enterprise. New York: St-Martin's Press.

4. Coviello, N.E., McAuley, A. (1999). Internationalisation and the smaller firm: a review of contemporary empirical research. MIR: Management International Review, 223-256.

5. Di Gregorio, D., Musteen, M., Thomas, D.E. (2008). International new ventures: The cross-border nexus of individuals and opportunities. Journal of World Business, 43(2), 186-196.

6. Dominguez, N., Mayrhofer, U. (2017). Internationalization stages of traditional SMEs: Increasing, decreasing and re-increasing commitment to foreign markets. International Business Review, 26(6), 1051-1063.

7. Doole, I., Grimes, T., Demack, S. (2006). An exploration of the management practices and process most closely associated with levels of export capability in SMEs. Marketing Intelligence \& Planning, 24(6), 632-647.

8. Dunning, J.H. (1998). Location and the multinational enterprise: a neglected factor? Journal of international Business Studies, 29(1), 45-66.

9. Forsgren, M. (2002). The concept of learning in the Uppsala internationalization process model: a critical review. International Business Review, 11(3), 257-277. 
10. Gemser, G., Brand, M.J., Sorge, A. (2004). Exploring the internationalisation process of small businesses: a study of Dutch old and new economy firms. MIR: Management International Review, 127-150.

11. Gilroy, B.M. (1993). Networking in Multinational Enterprises: The Importance of Strategic Alliances. Columbia, SC: University of South Carolina Press.

12. Hutchinson, K., Alexander, N., Quinn, B. (2005). The internationalisation of small to medium-sized retail firms: towards a conceptual framework. Journal of Marketing Management, 21, 149-179.

13. Johanson, J., Vahlne, J-E., (1977). The Internationalization Process Of The Firm - A Model Of Knowledge Development And Increasing Foreign Market Commitments. Journal of International Business Studies, 8(1), pp. 23-31.

14. Johanson, J., Vahlne, J.E. (2009). The Uppsala internationalization process model revisited: From liability of foreignness to liability of outsidership. Journal of International Business Studies, 40(9), 1411-1431.

15. Johanson, J., Vahlne, J.E. (2011). Markets as networks: implications for strategy-making. Journal of the Academy of Marketing Science, 39(4), 484-491.

16. Kalinic, I., Forza, C. (2012). Rapid internationalization of traditional SMEs: Between gradualist models and born globals. International Business Review, 21(4), 694-707.

17. Knight, G.A., Liesch, P.W. (2016). Internationalization: From incremental to born global. Journal of World Business, 51(1), 93-102.

18. Laffranchini, G., Hadjimarcou, J.S., Kim, S.H., Braun, M. (2016). The internationalization of family-firms: a signal detection approach. Journal of Family Business Management, Vol. 6, No. 3, pp. 291-309.

19. Laghzaoui, S. (2011). SMEs' internationalization: an analysis with the concept of resources and competencies. Journal of Innovation Economics Management, 1, 181-196.

20. Leonidou, L.C., Katsikeas, C.S. (1996). The export development process: an integrative review of empirical models. Journal of International Business Studies, 27(3), 517-551.

21. Lu, J.W., Beamish, P.W. (2001). The Internationalization and Performance of SMEs. Strategic Management Journal, 22, 565-586.

22. Matthews, J.A., Zander, I. (2007). The international entrepreneurial dynamics of accelerated internationalization. Journal of International Business Studies, 38(3), 387-403.

23. McDougall, P., Oviatt, B.M. (2000). International entrepreneurship: the intersection of two research paths. Journal of Small Business Management, 43(5), 902-909.

24. Miesenböck, K.J. (1988). Small Business And Exporting: A Literature Review. International Small Business Journal, 6(2), 42-61.

25. Pantin, F. (2006). L'internationalisation: un défi pour les compétences de l'équipe dirigeante d'une PME. Gestion, 31(1), 77-87.

26. Rialp, A., Rialp, J. (2001). Conceptual frameworks on SMEs' internationalization: Past, present and future trends of research. Advances in International Marketing, 11(1), 49-78. 
27. Ruzzier, M.R., Hisrich, D., Antoncic, B. (2006). SME internationalization research: past, present and future. Journal of Small Business Enterprise Development, vol. 13, no. 4, 476-497.

28. Szulc, T. (2020). Procesy internacjonalizacji regionu na przykładzie Emilia-Romagna we Włoszech. In: K. Wodarski, M. Krannich (Eds.), Internacjonalizacja małych i średnich przedsiębiorstw - polskie i europejskie doświadczenia. Toruń: Towarzystwo Naukowe Organizacji i Kierowania.

29. Vahlne, J.E., Johanson, J. (2013). The Uppsala model on evolution of the multinational business enterprise - from internalization to coordination of networks. International Marketing Review.

30. Williamson, O. (1975). Markets and Hierarchies. New York, NY: Free Press.

31. Wolniak, R. (2019). Main Problems of Business Enterprise Internationalization. Zeszyty Naukowe, Organizacja i Zarządzanie, Politechnika Ślaska, z. 136, 665-673.

32. Wolniak, R. (2020). Methods of Measurement of Enterprise Internationalization. Zeszyty Naukowe, Organizacja i Zarządzanie, Politechnika Śląska, z. 144, 665-673. 